\title{
Removal of a synthetic broad-spectrum antimicrobial agent, triclosan, in wastewater treatment systems: A short review
}

\author{
Do Gyun Lee ${ }^{\dagger}$ \\ Earth Research Institute, University of California, Santa Barbara, California 93106, USA
}

\begin{abstract}
Contaminants of emerging concern (CECs) including endocrine disrupting compounds (EDCs) and pharmaceuticals and personal care product chemicals (PPCPs) have recently received more attention because of their occurrence in water bodies and harmful impacts on human health and aquatic organisms. Triclosan is widely used as a synthetic broad-spectrum antimicrobial agent due to its antimicrobial efficacy. However, triclosan detected in aquatic environment has been recently considered as one of CECs, because of the potential for endocrine disruption, the formation of toxic by-products and the development of cross-resistance to antibiotics in aquatic environment. This comprehensive review focuses on the regulations, toxicology, fate and transport, occurrence and removal efficiency of triclosan. Overall, this review aims to provide better understanding of triclosan and insight into application of biological treatment process as an efficient method for triclosan removal.
\end{abstract}

Keywords: Antimicrobial, Contaminants of emerging concern (CECs), Pharmaceuticals and personal care product chemicals (PPCPs), Removal, Triclosan, Wastewater

\section{Introduction}

A public health concern about triclosan has recently emerged due to its widespread occurrence in wastewater, surface waters, sediment, soils, and even in urine, human blood, and breast milk [1-10]. Triclosan has been incorporated into numerous personal care, household, and industrial products since 1965, due to its effectiveness as a broad-spectrum antimicrobial agent [11, 12]. Global production of triclosan was estimated to exceed 1,500 tons per year, of which more than $43 \%$ of the production was used in the US and Europe [10, 13].

Once triclosan is released into the environment, triclosan can be potentially transformed into more toxic compounds, like chlorodioxins, chlorophenol, chloroform, p-hydroquinone, and 2,4-dichlorophenol when interacted with strong oxidants or under UV light [14]. Furthermore, trace levels of triclosan could promote the development of cross-resistance to antibiotics [15], and cause adverse health effects within the ecosystem [16]. Triclosan is also a weak androgenic and estrogenic compound [17-19].

Through commercial or residential washing of equipment outdoors with triclosan-containing products, triclosan may be transported into the stormwater drain systems; untreated triclosan is released directly into creeks, rivers, and ultimately to the Bay.
Moreover, wastewater is a major source of triclosan to the environment due to incomplete removal of triclosan by conventional wastewater treatment processes. Researchers have been actively seeking effective treatment strategies for triclosan and this task is challenging. Many advanced physical/chemical processes like UV irradiation, ozonation, sorption, advanced oxidation processes [10, 20-28] have shown effectiveness for triclosan removal. Biodegradation of triclosan by many fungi, bacterial consortia, activated sludge and pure strains has also been reported [29-36], suggesting that biological removal of triclosan could be an alternative treatment method for triclosan removal.

\section{Chemical Property and Regulations}

Triclosan (5-chloro-2-(2,4-dichlorophenoxy)phenol; CAS 3380-34-5) is a nonionic, lipophilic, and chlorinated phenolic compound that has been used as a synthetic broad-spectrum antimicrobial agent, since the Ciba Specialty Chemicals (Basel, Switzerland) first produced triclosan in 1965 [11, 12]. Due to its effective antimicrobial ability, triclosan has been widely incorporated into numerous personal care and household products, and industrial products such as deodorants, soaps, skin cream, toothpastes, laundry detergents, socks, sport
This is an Open Access article distributed under the terms of the Creative Commons Attribution Non-Commercial License (http://creativecommons. org/ licenses/by-nc/3.0/) which permits unrestricted non-commercial use, distribution, and reproduction in any medium, provided the original work is properly cited.
Received November 30, 2014 Accepted March 2, 2015

$\uparrow$ Corresponding author

Email: dlee@bren.ucsb.edu

Tel: +1-805-893-3489 Fax: +1-805-893-2578 
footwear, toys, fabrics, computer keyboards, countertops, and many different plastic kitchenware all over America, Europe and Asia. Triclosan has been globally produced over 1,500 tons per year, especially, more than 300 tons and 350 tons of triclosan are yearly used in the US and in Europe, respectively [10, 13].

Triclosan is referred to as halogenated biphenyl ether due to functional groups of ether and phenol. Alternative names for triclosan include 2,4,4'-trichloro-2'-hydroxydiphenyl ether, 5-chloro-2(2,4-dichlorophenoxy)phenol or trichloro-2'-hydroxydiphenyl ether. In addition, triclosan has commercial names such as Irgasan DP-300, Lexol 300, Ster-Zac, Cloxifenolum, Microban in plastics and clothing, and Biofresh in acrylic fibers [7]. The chemical formula for triclosan is $\mathrm{C}_{12} \mathrm{H}_{7} \mathrm{Cl}_{3} \mathrm{O}_{2}$ and its molecular weight is 289.55 $\mathrm{g} / \mathrm{mol}$. Triclosan is white to off-white crystalline powder with a hardly detectable phenolic odor. Triclosan is thermally stable; it has a melting point between $56-60^{\circ} \mathrm{C}$ and a boiling point between $280-290^{\circ} \mathrm{C}$ [37]. Triclosan is relatively non-volatile and non-soluble in water (solubility: $10 \mathrm{mg} / \mathrm{L}$ at $20^{\circ} \mathrm{C}$; $\log \mathrm{K}_{\mathrm{ow}}=4.76$ ), but readily soluble in a wide range of organic solvents $[37,38]$. The chemical structure of triclosan (Fig. 1) is similar to several emerging contaminants such as polybrominated diphenyl ethers (PBDEs), polychlorinated biphenyls (PCBs), dioxine, biphenol A, diethylstilbestrol (synthetic nonsteroidal estrogen), and thyroxine (thyroid hormone) [39-41]. Triclosan has been banned in Canada and Japan. In the European Union, triclosan is categorized as a dangerous irritant to the environment and aquatic life [42]. The use of triclosan in food contact plastics was banned in September 2009 in Germany. It has been advised to consumers not to use antibacterial products in Finland and Denmark [43]. In the U.S., the non-pesticide use of triclosan is regulated by the U.S. Food and Drug Administration (FDA), while the pesticide use of triclosan is regulated by the Environmental Protection Agency (EPA). However, the regulation for triclosan in surface waters has not been established.

\section{Toxicology of Triclosan}

Triclosan has a low level of toxicity to humans and other mammals $[38,44]$. Triclosan showed a low acute toxicity in animal studies that the dermal $\mathrm{LD}_{50}$ (median lethal dose) is $5,000 \mathrm{mg} / \mathrm{kg}$ for rats, and the oral $\mathrm{LD}_{50}$ are $4,000 \mathrm{mg} / \mathrm{kg}$ for mice, $4,500-5,000 \mathrm{mg} / \mathrm{kg}$ for rats, and over $5,000 \mathrm{mg} / \mathrm{kg}$ for dogs [37]. One study in male mice also reported that triclosan showed a low acute toxicity $\left(\mathrm{LD}_{50}>\right.$
$1,000 \mathrm{mg} / \mathrm{kg}$ ) [45]. However, several studies reported that triclosan is acutely and chronically toxic to several different types of aquatic life such as fish and algae in the range of 34.2-200 $\mu \mathrm{g} / \mathrm{L}$ [46-49]. Ricart et al. [50] reported that triclosan caused an increase in bacterial mortality with a no effect concentration (NEC) of 0.21 $\mu \mathrm{g} / \mathrm{L}$ and it was more toxic to bacteria than algae. As shown in two fish studies, the acute toxicity of triclosan depended on the different life stages of species, especially, showing more toxic effects on juveniles [51, 52].

\subsection{Triclosan as a Class of Endocrine Disrupting Compounds (EDCs)}

Several studies reported that triclosan is a thyroid disruptor in animals due to the structural similarity of triclosan to thyroid hormones such as thyroxine [39-41, 53]. Damage caused by disrupting thyroid systems may affect normal growth and development of humans, especially, the development of children's brain. Using frogs that have a primary thyroid hormone-signaling mechanism which is almost identical to human's, several studies showed that low levels of triclosan interfered with thyroid-mediated developmental processes of tadpoles into frogs [39, 54, 55]. Further, triclosan may disrupt other critical hormone systems in mammals due to the structural similarity to anthropogenic estrogens (bisphenol A and diethylstilbestrol), and the anti-estrogen $(2,3,7,8$ tetrachloro-p-dioxin) [56]. An in-vitro study showed that triclosan exerted androgenic and estrogenic activities in human breast cancer cells [17]. In-vivo fish studies suggested that triclosan act as anti-estrogen [57] or weak androgen [18]. Several male rat studies demonstrated that triclosan lowered serum levels of testosterone and several steroidogenic enzyme activities $[58,59]$. One study also reported that a triclosan metabolite may have a weak estrogenic activity [47].

\subsection{Development of Antibiotic Cross-resistance}

Several studies raised a concern that triclosan may promote the development of cross-resistance to antibiotics in microorganisms and lead to the emergence of bacteria resistant to antibiotics in the environment. While antimicrobial agents are generally not intended to destroy particular cellular constituents in bacteria, antibiotics attack specific cellular target to inhibit the growth of cell and the synthesis of cell wall or cell contents [60]. Because triclosan kills bacteria in a similar way as antibiotics by inhibiting the active sites of the specific bacterial fatty acid biosynthetic enzyme, enoyl-acyl carrier protein reductase, which is necessary<smiles>CC/C(=C(/CC)c1ccc(O)cc1)c1ccc(O)cc1</smiles>

Fig. 1. Chemical structure of triclosan, bisphenol A, diethylstilbestrol, and thyroxine. 
to build and reproduce cell membranes [61], bacteria that become resistant to triclosan may have the potential of antibiotic resistance. A laboratory study found the cross-resistance between triclosan and ciprofloxacin (oral antibiotic) in Pseudomonas aeruginosa [62]. There is no evidence that triclosan can cause a mutation in bacteria. However, since triclosan kills normal bacteria that are susceptible to triclosan in the environment, mutated bacteria that are resistant to triclosan are more likely to survive and be reproduced in the triclosan contaminated environment. A laboratory study found that a number of different strains of mutant bacteria that are resistant to triclosan also showed the resistance to a number of clinical-use antibiotics [63].

\section{Source, Occurrence, Fate and Transport in the Environment}

Urban waters are vulnerable to anthropogenic contamination by human activities and could be polluted with a long-term impact on the urban aquatic ecosystem. Urban wastewater stream can be one of major pathways for emerging organic contaminants including triclosan and these contaminants could be carried in surface and subsurface in urban catchments in association with migration, sorption, transformation processes such as photo-degradation, chemical or biological transformation in urban water systems (Fig. 2) [64].

Since triclosan is primarily a water-borne contaminant, it is detected ubiquitously in aquatic environments at some of the highest concentrations among 95 organic wastewater pollutants [3]. Disposal and usage of triclosan-laden products resulted in triclosan-containing wastewater. About $96 \%$ of household and consumer products containing triclosan flows down the drain [65]. Of the triclosan eventually entering wastewater treatment plants (WWTPs), 79\% is biodegraded, 15\% is adsorbed onto biosolids, and the remaining $6 \%$ is discharged continuously into the receiving surface water $[1,10]$. Triclosan can be also released into the environment via the application of biosolids to an agricultural field and irrigation of treated wastewater contaminated with triclosan [10, 66, 67]. Consumer product wastes containing triclosan, and sludge from wastewater treatment plants are mostly sent to landfill for disposal, and triclosan can be released into the environment

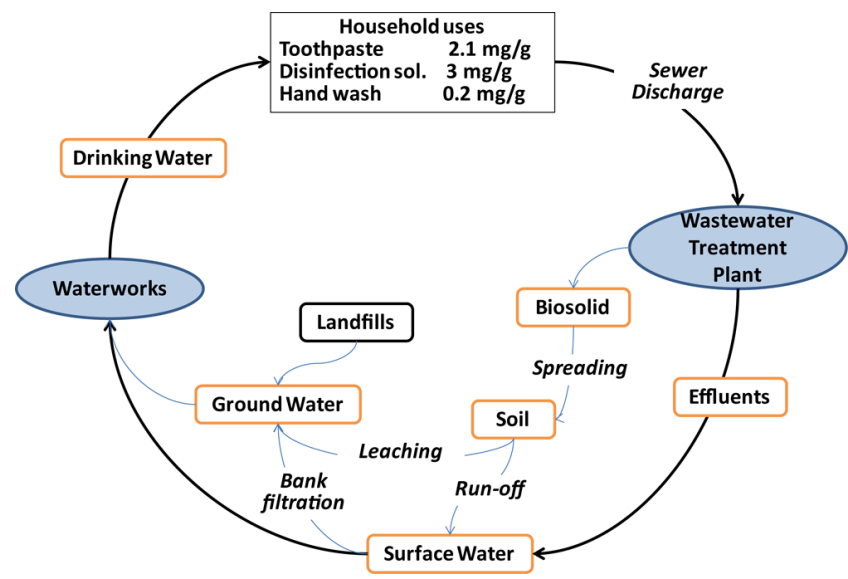

Fig. 2. Life cycle of triclosan in the aquatic environment [64]. through landfill leachate [68]. In addition, through commercial or residential washing of equipment outdoors with triclosan-containing products, runoff containing triclosan goes into stormwater drain systems without treatment, and flows directly into creeks, rivers and eventually to the bay or oceans.

Triclosan concentrations in wastewater influents in Korea, United States, Europe, China, and Japan range from 148 to 785, 245 to $86,200,142$ to 2,301 and 55 to $1,000 \mathrm{ng} / \mathrm{L}$, respectively $[64,69,70]$. Triclosan in wastewater effluents in Korea, United States, Europe, China, and Japan are detected at the concentrations between 0-127, 50-5,037, 10-2,210, 10.9-1,023, and 30-360 ng/L, respectively $[1,2,10,64,69,71-74]$. In surface river water, triclosan was detected in Korea, United States, Europe, China, and Japan with reported values varying from 0 to $149,3.5$ to $34.9,<0.2$ to $285,2.5$ to 478 and 11 to 31 , respectively [64, 69, 70, 75]. A recent USGS study also reported that approximately $58 \%$ of 139 U.S. streams were contaminated with triclosan at the concentrations ranging from 0.14 to $2.3 \mu \mathrm{g} / \mathrm{L}$ [3]. Triclosan was found in lake-, marine-, and river-sediments at the concentrations in the range from 37 to $53 \mathrm{ng} / \mathrm{g}$, from 0.27 to $130.7 \mathrm{ng} / \mathrm{g}$, and from 4.4 to 35.7 ng/g, respectively [10, 76, 77]. Lapworth et al. [78] reported triclosan concentrations found in groundwater ranging between 7-2,110 ng/L. The ranges of triclosan concentrations detected in WWTP influents, WWTP effluents, and surface river water in the different countries are briefly summarized in Table 1 .

Triclosan concentrations in activated sludge have been detected in the range of 500 to $15,600 \mu \mathrm{g} / \mathrm{kg}$ of dry weight [71, 79]. Triclosan in biosolids have been detected at the concentrations between 90 and $30,000 \mu \mathrm{g} / \mathrm{kg}[4,79-82]$. Triclosan was also detected at concentrations ranging from 69 to $833 \mathrm{ng} / \mathrm{g}$ in agricultural soil amended with biosolids [4]. Furthermore, biosolid application to an agricultural field and the irrigation of treated wastewater containing triclosan contributed to triclosan detection in vegetation contributed from [66, 67]. One field study reported that triclosan in soybean plants was detected at the concentrations between 36 and $80 \mathrm{ng} / \mathrm{g}$ of dry weight from irrigation treatment samples, and between 13 and $136 \mathrm{ng} / \mathrm{g}$ of dry weight from biosolids application treatment samples [83].

In addition to triclosan detection in the environment, triclosan was detected in $75 \%$ of 2,517 human urine samples at concentrations of $2.4-3,790 \mu \mathrm{g} / \mathrm{L}$ [84] and in the $61 \%$ of 90 urine samples from age 6-8 year-old girls [85]. Triclosan was also found in human blood [6, 8, 41, 86]; for example, triclosan was detected in the range between 4.1-19 ng/g in blood serum samples [41]. Triclosan in the range of $100-2,100 \mu \mathrm{g} / \mathrm{kg}$ of lipid was detected in the $96.8 \%$ of 62 samples of breast milk [9] and concentrations of triclosan in breast milk ranged from 0.018 to $0.95 \mathrm{ng} / \mathrm{g}$ [8]. Moreover, triclosan was found in indoor dusts $(\sim 1.1 \mu \mathrm{g} / \mathrm{g})$ [87], and foods (0.02-0.15 $\mathrm{ng} / \mathrm{g})$ such as dairy products, meat, fish and egg [88].

Triclosan released into the environment can be transformed into more toxic products through photodegradation and/or biodegradation. Under anaerobic conditions, methylation of triclosan into methyl-triclosan in surface waters and wastewater has been reported [89]. Due to the lipophilic property of methyl-triclosan $\left(\mathrm{K}_{\mathrm{ow}}=5.2\right)$, it may bioacummulate in wildlife and human. A fish study found the concentrated methyl-triclosan in fatty tissue [90] and another study reported that methyl-triclosan has acute toxicities in the marine bacterium Vibrio fischeri at low 
Table 1. Occurrence and Concentrations of Triclosan in WWTP Influent, WWTP Effluent and Surface water in the Different Countries

\begin{tabular}{llcc}
\hline Location & $\begin{array}{c}\text { Concentration } \\
\text { (ng/L) }\end{array}$ & Reference \\
\hline WWTP influent & Korea & $148-460$ & {$[69]$} \\
& Korea & $280-745$ & {$[69]$} \\
& Korea & $247-785$ & {$[70]$} \\
& United States & $245-86,200$ & {$[64]$} \\
& Europe & $52-21,900$ & {$[64]$} \\
& China & $142-2,301$ & {$[64]$} \\
& Japan & $55-1,000$ & {$[64]$} \\
WWTP effluent & Korea & $0-29.6$ & {$[69]$} \\
& Korea & $0-127$ & {$[69]$} \\
& Korea & $1.3-32$ & {$[73]$} \\
& Korea & $5.6-16$ & {$[74]$} \\
& United States & $50-5,370$ & {$[64]$} \\
& Europe & $10-2,210$ & {$[64]$} \\
& China & $10.9-1,023$ & {$[64]$} \\
& Japan & $30-360$ & {$[64]$} \\
\hline Surface river water & Korea & $0-46.1$ & {$[69]$} \\
& Korea & $1-29$ & {$[75]$} \\
& Korea & $16-82$ & {$[75]$} \\
& Korea & $79-149$ & {$[70]$} \\
& United States & $3.5-34.9$ & {$[64]$} \\
& Europe & $<0.2-285$ & {$[64]$} \\
& China & $2.5-478$ & {$[64]$} \\
& Japan & $11-31$ & {$[64]$} \\
\hline
\end{tabular}

levels [91]. A great concern about the rapid transformation of triclosan into 2,8-dichlorodibenzo- $p$-dioxin (2,8-DCDD) during the photo-degradation in natural water and wastewater has been raised [14, 92-96] because dioxin is highly carcinogenic and can cause such severe health problems as affecting reproductive abilities and weakening the immune system [97]. Triclosan can be transformed into chlorophenols (2,4-dichlorophenol and 2,4,6-trichlorophenol) in the presence of chlorine [98-100] or chloramines [101]. These chlorophenols are listed as the priority pollutants by EPA, and are potentially toxic and stable in the environment [98]. Recent studies have shown that triclosan in tap/surface water or in common triclosan-containing hygienic products reacts with residual chlorine to form potentially carcinogenic chloroform [99-101].

\section{Treatment Technologies for Triclosan Removal}

\subsection{Physical/Chemical Removal of Triclosan}

A granular activated carbon (GAC) treatment system was effective by decreasing $2,032 \mathrm{ng} / \mathrm{L}$ of triclosan concentration in influent to $102 \mathrm{ng} / \mathrm{L}$ in effluent [102]. Powdered activated carbon achieved 95\% of triclosan reduction during drinking water treatment [103]. Different sorbents such as kaolinite and montmorillonite are effective for triclosan removal [28]. Advanced membrane technologies such as nanofiltration/reverse osmosis membranes are effective
Table 2. Triclosan Removal Efficiencies by Different Treatments

\begin{tabular}{lcc}
\hline \multicolumn{1}{c}{ Treatment } & $\begin{array}{c}\text { Removal } \\
\text { efficiency (\%) }\end{array}$ & Reference \\
\hline Granular activated carbon & $95 \%$ & {$[102]$} \\
Powdered activated carbon & $95 \%$ & {$[103]$} \\
Ultrasonication & $60 \%$ & {$[105]$} \\
Conventional Sand filtration & $0 \%$ & {$[106]$} \\
$\mathrm{UV}$ irradiation & $93 \%$ & {$[26]$} \\
Ozonation & $58-100 \%$ & {$[23]$} \\
$\mathrm{UV} / \mathrm{H}_{2} \mathrm{O}_{2}$ & $>95 \%$ & {$[107]$} \\
$\mathrm{UV} / \mathrm{TiO}{ }_{2}$ & $75-82 \%$ & {$[108]$} \\
TiO ${ }_{2}$ & $30 \%$ & {$[108]$} \\
$\mathrm{UV} / \mathrm{Fe}$ (II) & $100 \%$ & {$[109]$} \\
Electo-oxidation & $>90 \%$ & {$[110]$} \\
Activated sludge & $95-98 \%$ & {$[111]$} \\
Trickling filter & $86-97 \%$ & {$[111]$} \\
Rotating biological contactors & $58-96 \%$ & {$[111]$} \\
Primary treatment & $32 \%$ & {$[71]$} \\
\hline
\end{tabular}

for triclosan removal, but more expensive than other treatment options [104]. $60 \%$ of initial triclosan in domestic wastewater was removed by ultrasonication [105]. However, conventional sand filtration showed no removal of triclosan [106].

Triclosan can be effectively removed by chemical oxidation processes including UV irradiation, ozonation, UV/hydrogen peroxide-advanced oxidation process and chlorination. One study reported that $93 \%$ of initial triclosan was removed by UV irradiation in wastewater [26]. Ozonation can rapidly oxidize triclosan during wastewater treatment [23]. UV/hydrogen peroxide-advanced oxidation process showed high removal efficiency of triclosan [107]. Triclosan was degraded during chlorination at neutral $\mathrm{pH}$ (7.3-8.3) [98]. UV light in combination with $\mathrm{TiO}_{2}$ achieved a $75-82 \%$ reduction in triclosan, whereas $30 \%$ of triclosan was removed by $\mathrm{TiO}_{2}$ as a sole oxidant [108]. Triclosan was almost completely removed within $60 \mathrm{~min}$ by UV/Fe (II) [109]. Oxidants such as manganese oxides $\left(\delta-\mathrm{MnO}_{2}\right.$ and $\left.\mathrm{MnOOH}\right)$, titanium dioxide, permanganate (Mn (VII)), and Fe (III)-saturated montmorillonite have shown to oxidize triclosan effectively [20-24, 105]. A recent study demonstrated $>99.9 \%$ of degradation efficiency via electrochemical degradation at $\mathrm{Ti} / \mathrm{SnO}_{2}-\mathrm{Sb} / \mathrm{Ce}-\mathrm{PbO}_{2}$ anodes [110].

\subsection{Biological Removal of Triclosan}

Several studies reported triclosan removal in wastewater treatment plants (WWTPs) by biological treatment process [10, 71, 111, 112]. The removal efficiency of triclosan is dependent on the operations and configurations of WWTPs. Thompson et al. reported that overall removal of triclosan ranged between 95-98\% (activated sludge), 86-97\% (trickling filter), and 58-96\% (rotating biological contactors) [111]. McAvoy et al. also found that triclosan was removed with rates of $96 \%, 71 \%$, and $32 \%$ for activated sludge plants, trickling filter plants, and primary treatment plants, respectively [71]. In general, activated sludge treatment enables the greatest removal of triclosan. One study estimated that $79 \%$ and $15 \%$ of triclosan 
was removed by biodegradation and adsorption onto biosolids, respectively, and then the remaining $6 \%$ of triclosan was discharged into the receiving water [10].

Several studies demonstrated the aerobic biodegradation of triclosan by wastewater enrichment consortium [29, 30], nitrifying activated sludge [32], wastewater microorganisms (Sphingomonas sp. Rd1 and Sphingomonas sp. PH-07) [29, 34], soil microorganisms [31], and two white rot fungi (Trametes versicolor and Pycnoporus cinnavarinus) [33]. A recent study demonstrated the $72 \%$ of maximum triclosan biodegradation yield at $7.5 \mathrm{mg} / \mathrm{L}$ of triclosan concentration by Aspergillus versicolor [113]. $0.15-0.18 \mu \mathrm{g} / \mathrm{mL}$ of triclosan was degraded cometabolically by all these known strains and cultures. The two soil bacteria, Pseudomonas putida TriRY and Alcaligenes xylosoxidans subsp. denitrificans TR1 utilized triclosan as a carbon source and degraded it within 4 days and 10 days, respectively [31]. One study suggested that a diphenyl-ether degrad- ing bacterium, Sphingomonas sp. PH-07 used 2,3-dioxygease enzyme to cometabolically degrade $25 \%$ of $10 \mathrm{mg} / \mathrm{L}$ triclosan in 8 days and proposed a possible degradation pathway for triclosan [34]. The degradation pathways of triclosan by a new wastewater isolate, Sphingopyxis strain KCY1, and several oxygenase-expressing bacteria have elucidated (Fig. 3) [35, 36]. The phylogenetic diversity of triclosan-utilizing bacteria was investigated in activated sludge systems using DNA-based stable-isotope probing technique [114]. An ammonia-oxidizing bacterium (AOB), Nitrosomonas europaea were found to cometabolically degrade $45 \%$ of $1 \mathrm{mg} / \mathrm{L}$ triclosan within 24 hours [32]. This study also demonstrated that ammonia monooxygenase in Nitrosomonas europaea was involved in triclosan biodegradation.

While triclosan in aerobic condition shows relatively rapid degradation; triclosan is slowly degraded or persistent under anaerobic condition. Anaerobic degradation of triclosan was not observed<smiles>Oc1cc(Cl)ccc1Oc1ccc(Cl)cc1Cl</smiles>

5-chloro-2-(2,4-dichlorophenoxy)phenol<smiles>CC(C)[C@H]1C(O)=CC(Cl)[C@H](O)[C@@H]1Oc1ccc(Cl)cc1Cl</smiles>

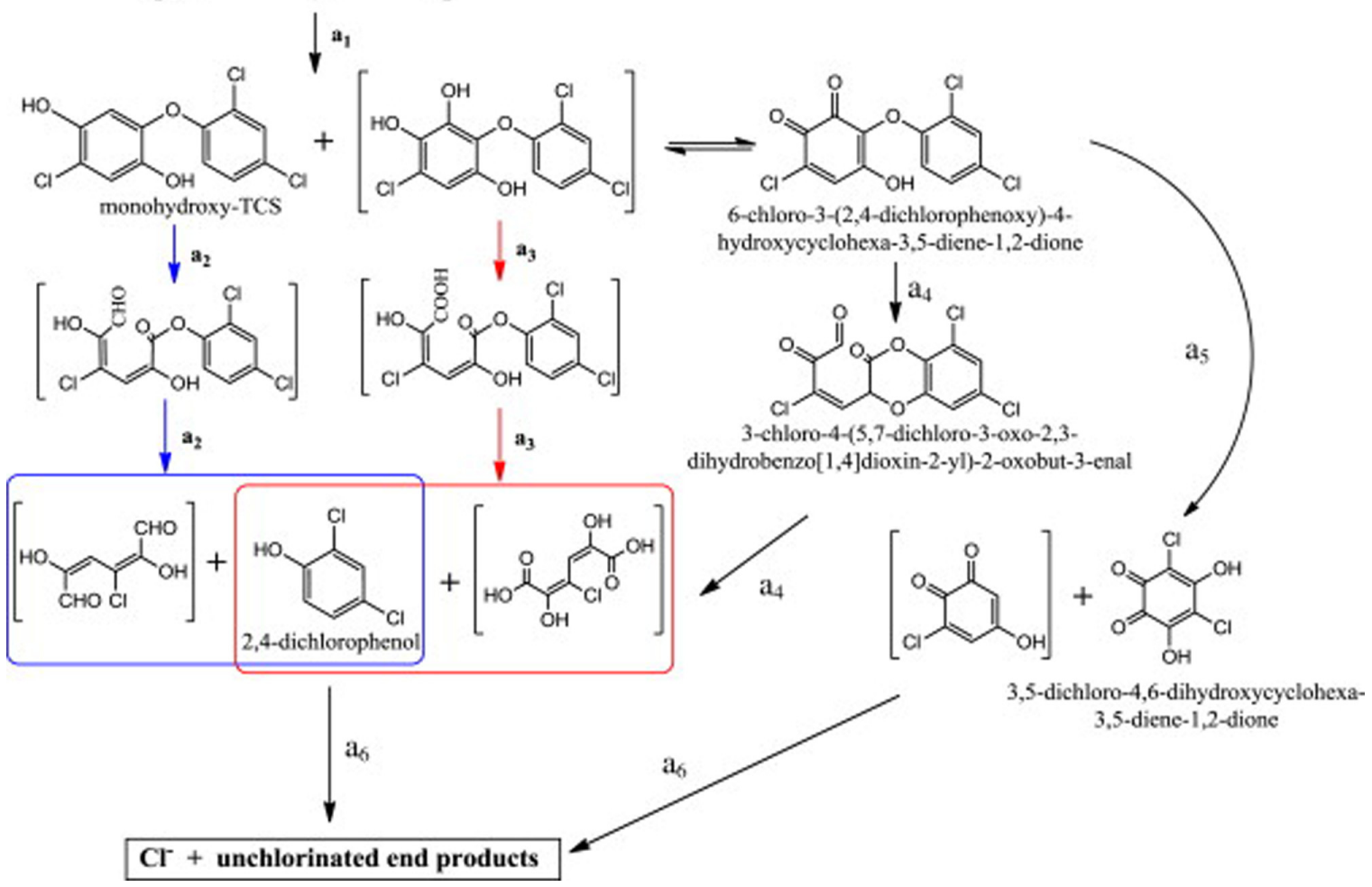

Fig. 3. Triclosan biodegradation pathway by a wastewater microorganism [35]. 
in 70 days [115]. Similarly, a study reported remaining of $91 \%$ of ${ }^{14} \mathrm{C}$-triclosan after incubation under anaerobic conditions for 147 days [106]. One study reported that anaerobic triclosan biodegradation was not observed, but $75 \%$ of triclosan removal by aerobic activated sludge after 150-hr incubation [116].

\section{Conclusion and Recommendation}

Triclosan is a common synthetic antimicrobial agent incorporated in numerous industrial and personal care products. However, the detection of triclosan in the environment has raised a public health concern, because the exposure of triclosan may promote the development of the cross-resistance to antibiotics, cause endocrine disruption to aquatic microorganisms, and potentially form more toxic by-products. Wastewater is one major source for environmental triclosan due to its incomplete removal by conventional wastewater treatment processes. Many advanced physical/chemical processes have shown effective removal for triclosan. However, these methods may be costly and potentially generate more toxic by-products. Approximately $80 \%$ of triclosan loading in wastewater treatment plants (WWTPs) can be rapidly biodegraded by microorganisms [29-34], suggesting that the biological removal of triclosan could be an inexpensive and effective alternative for triclosan removal.

Therefore, the knowledge of the microbiology with respect to triclosan biodegradation by investigating microorganisms capable of degrading triclosan, their degradative enzymes, and degradation pathways for triclosan is essential for developing an effective treatment strategy for triclosan removal in wastewater. Additional research about microorganisms in term of their degradation ability toward triclosan is required. Known microorganisms that are capable of degrading other xenobiotics with the similar chemical structure to triclosan, and that exhibit the metabolism or cometabolism of a wide variety of these toxic pollutants could be potential candidates as a bioaugmentation agent for biological treatment systems.

Furthermore, sequencing the complete genome of microorganisms capable of degrading triclosan will provide insights into factors regulating the unique enzymatic system for either metabolic or cometabolic degradation of triclosan. The availability of the genome sequence will significantly accelerate the analysis of the genes and enzymes involved in triclosan degradation. Eventually, the information obtained from the genome sequences of triclosan-degrading microorganisms would be useful to develop advanced biological treatment processes for triclosan removal.

It is also important to note that microcosm studies of triclosan biodegradation in true environment is needed to provide comprehensive information of degradation kinetics at ambient concentrations by indigenous microorganisms present in natural conditions for the representative of the true environment such as contaminated hazard waste sites, wastewater or receiving surface waters by considering the interactions with other species in indigenous microbial community, oxygen, nitrogen sources, cell densities, inducing substrates and nutrient conditions, $\mathrm{pH}$ and temperature.

\section{References}

1. Morrall D, McAvoy D, Schatowitz B, et al. A field study of triclosan loss rates in river water (Cibolo Creek, TX). Chemosphere 2004;54:653-660.

2. Nakada N, Yasojima M, Okayasu Y, Komori K, Suzuki Y. Mass balance analysis of triclosan, diethyltoluamide, crotamiton and carbamazepine in sewage treatment plants. Water Sci. Technol. 2010;61:1739-1747.

3. Kolpin DW, Furlong ET, Meyer MT, et al. Response to comment on "Pharmaceuticals, hormones, and other organic wastewater contaminants in US streams, 1999-2000: A national reconnaissance". Environ. Sci. Technol. 2002;36:4004.

4. Kinney CA, Furlong ET, Kolpin DW, et al. Bioaccumulation of pharmaceuticals and other anthropogenic waste indicators in earthworms from agricultural soil amended with biosolid or swine manure. Environ. Sci. Technol. 2008;42:1863-1870.

5. Queckenberg C, Meins J, Wachall B, et al. Absorption, pharmacokinetics, and safety of triclosan after dermal administration. Antimicrob. Agents Chemother. 2010;54:570-572.

6. Sandborgh-Englund G, Adolfsson-Erici M, Odham G, Ekstrand J. Pharmacokinetics of triclosan following oral ingestion in humans. J. Toxicol. Environ. Health A 2006;69:1861-1873.

7. Adolfsson-Erici M, Pettersson M, Parkkonen J, Sturve J. Triclosan, a commonly used bactericide found in human milk and in the aquatic environment in Sweden. Chemosphere 2002;46:1485-1489.

8. Allmyr M, Adolfsson-Erici M, McLachlan MS, SandborghEnglund G. Triclosan in plasma and milk from Swedish nursing mothers and their exposure via personal care products. Sci. Total Environ. 2006;372:87-93.

9. Dayan AD. Risk assessment of triclosan [Irgasan] in human breast milk. Food Chem. Toxicol. 2007;45:125-129.

10. Singer H, Mueller S, Tixier C, Pillonel L. Triclosan: occurrence and fate of a widely used biocide in the aquatic environment: field measurements in wastewater treatment plants, surface waters, and lake sediments. Environ. Sci. Technol. 2002;36: 4998-5004.

11. Yazdankhah SP, Scheie AA, Hoiby EA, et al. Triclosan and antimicrobial resistance in bacteria: an overview. Microb. Drug Resist. 2006;12:83-90.

12. Schweizer HP. Triclosan: a widely used biocide and its link to antibiotics. FEMS Microbiol. Lett. 2001;202:1-7.

13. Halden RU, Paull DH. Co-occurrence of triclocarban and triclosan in US water resources. Environ. Sci. Technol. 2005;39: 1420-1426.

14. Latch DE, Packer JL, Arnold WA, McNeill K. Photochemical conversion of triclosan to 2,8-dichlorodibenzo-p-dioxin in aqueous solution. J. Photochem. Photobiol. A Chem. 2003;158: 63-66.

15. Braoudaki M, Hilton AC. Low level of cross-resistance between triclosan and antibiotics in Escherichia coli K-12 and E. coli O55 compared to E.coli O157. FEMS Microbiol. Lett. 2004;235: 305-309.

16. Tatarazako N, Ishibashi H, Teshima K, Kishi K, Arizono K. Effects of triclosan on varios aquatic organisms. Environ. Sci.: 
Int. J. Environ. Physiol. Toxicol. 2004;11:133-140.

17. Gee RH, Charles A, Taylor N, Darbre PD. Oestrogenic and androgenic activity of triclosan in breast cancer cells. J. Appl. Toxicol. 2008;28:78-91.

18. Foran CM, Bennett ER, Benson WH. Developmental evaluation of a potential non-steroidal estrogen: triclosan. Mar. Environ. Res. 2000;50:153-156.

19. Ishibashi $H$, Tachibana $K$, Tsuchimoto $M$, et al. Effects of nonylphenol and phytoestrogen-enriched diet on plasma vitellogenin, steroid hormone, hepatic cytochrome P450 1A, and glutathione-S-transferase values in goldfish (Carassius auratus). Comparative Med. 2004;54:54-62.

20. Jiang J, Pang SY, Ma J. Oxidation of triclosan by permanganate (Mn(VII)): importance of ligands and in situ formed manganese oxides. Environ. Sci. Technol. 2009;43:8326-8331.

21. Liyanapatirana C, Gwaltney SR, Xia K. Transformation of triclosan by Fe(III)-saturated montmorillonite. Environ. Sci. Technol. 2010;44:668-674.

22. Rafqah S, Wong-Wah-Chung P, Nelieu S, Einhorn J, Sarakha M. Phototransformation of triclosan in the presence of $\mathrm{TiO}_{2}$ in aqueous suspension: Mechanistic approach. Appl. Catal. $B$ Environ. 2006;66:119-125.

23. Suarez S, Dodd MC, Omil F, von Gunten U. Kinetics of triclosan oxidation by aqueous ozone and consequent loss of antibacterial activity: relevance to municipal wastewater ozonation. Water Res. 2007;41:2481-2490.

24. Zhang HC, Huang CH. Oxidative transformation of triclosan and chlorophene by manganese oxides. Environ. Sci. Technol. 2003;37:2421-2430.

25. Bokare V, Murugesan K, Kim YM, Jeon JR, Kim EJ, Chang YS. Degradation of triclosan by an integrated nano-bio redox process. Bioresour. Technol. 2010;101:6354-6360.

26. Sanchez-Prado L, Llompart M, Lores M, Garcia-Jares C, Bayona JM, Cela R. Monitoring the photochemical degradation of triclosan in wastewater by UV light and sunlight using solid-phase microextraction. Chemosphere 2006;65:1338-1347.

27. Tixier C, Singer HP, Canonica S, Muller SR. Phototransformation of triclosan in surface waters: a relevant elimination process for this widely used biocide - laboratory studies, field measurements, and modeling. Environ. Sci. Technol. 2002;36:3482-3489.

28. Behera SK, Oh SY, Park HS. Sorption of triclosan onto activated carbon, kaolinite and montmorillonite: effects of $\mathrm{pH}$, ionic strength, and humic acid. J. Hazard Mater. 2010;179:684-691.

29. Hay AG, Dees PM, Sayler GS. Growth of a bacterial consortium on triclosan. FEMS Microbiol. Lett. 2001;36:105-112.

30. Stasinakis AS, Kordoutis CI, Tsiouma VC, Gatidou G, Thomaidis NS. Removal of selected endocrine disrupters in activated sludge systems: effect of sludge retention time on their sorption and biodegradation. Bioresour. Technol. 2010; 101:2090-2095.

31. Meade MJ, Waddell RL, Callahan TM. Soil bacteria Pseudomonas putida and Alcaligenes xylosoxidans subsp denitrificans inactivate triclosan in liquid and solid substrates. FEMS Microbiol. Lett. 2001;204:45-48.

32. Roh H, Subramanya N, Zhao F, Yu CP, Sandt J, Chu KH. Biodegradation potential of wastewater micropollutants by ammonia-oxidizing bacteria. Chemosphere 2009;77:1084-1089.
33. Hundt K, Martin D, Hammer E, Jonas U, Kindermann MK, Schauer F. Transformation of triclosan by Trametes versicolor and Pycnoporus cinnabarinus. Appl. Environ. Microbiol. 2000;66:4157-4160.

34. Kim YM, Murugesan K, Schmidt S, et al. Triclosan susceptibility and co-metabolism - a comparison for three aerobic pollutant-degrading bacteria. Bioresour. Technol. 2011;102:2206-2212.

35. Lee DG, Zhao F, Rezenom YH, Russell DH, Chu KH. Biodegradation of triclosan by a wastewater microorganism. Water Res. 2012;46:4226-4234.

36. Lee DG, Chu KH. Effects of growth substrate on triclosan biodegradation potential of oxygenase-expressing bacteria. Chemosphere 2013;93:1904-1911.

37. Kroon AGM, van Ginkel CG. Complete mineralization of dodecyldimethylamine using a two-membered bacterial culture. Environ. Microbiol. 2001;3:131-136.

38. Bhargava HN, Leonard PA. Triclosan: applications and safety. Am. J. Infect. Control 1996;24:209-218.

39. Veldhoen N, Skirrow RC, Osachoff H, et al. The bactericidal agent triclosan modulates thyroid hormone-associated gene expression and disrupts postembryonic anuran development. Aquat. Toxicol. 2006;80:217-227.

40. Crofton KM, Paul KB, DeVito MJ, Hedge JM. Short-term in vivo exposure to the water contaminant triclosan: evidence for disruption of thyroxine. Environ. Toxicol. Pharmacol. 2007;24:194-197.

41. Allmyr M, Harden F, Toms LML, et al. The influence of age and gender on triclosan concentrations in Australian human blood serum. Sci. Total Environ. 2008;393:162-167.

42. Winter RA. Consumer's dictionary of cosmetic ingredients. 4th ed. New York: Crown Trade Paperbacks; 1994.

43. Fuerhacker M, Haile TD. Treatment and reuse of sludge. In: Barceló D, Petrovic M, Afferden M, eds. waste water treatement and reuse in the Mediterranean region. The Handbook Environ. Chem. Springer-Verlag Berlin Heidelberg; 2011(14). p. 63-92.

44. Rodricks JV, Swenberg JA, Borzelleca JF, Maronpot RR, Shipp AM. Triclosan: a critical review of the experimental data and development of margins of safety for consumer products. Crit. Rev. Toxicol. 2010;40:422-484.

45. Kanetoshi A, Katsura E, Ogawa H, Ohyama T, Kaneshima H, Miura T. Acute toxicity, percutaneous-absortion and effects on hepatic mixed-function oxidase activities of 2,4,4'-trichloro-2'-hydroxydiphenyl ether (Irgasan DP300) and its chlorinated derivatives. Arch. Environ. Contam. Toxicol. 1992;23:91-98.

46. DR Orvos, Versteeg DJ, Inauen J, et al. Aquatic toxicity of triclosan. Environ. Toxicol. Chem. 2002;21:1338-1349.

47. Ishibashi $\mathrm{H}$, Matsumura N, Hirano M, et al. Effects of triclosan on the early life stages and reproduction of medaka Oryzias latipes and induction of hepatic vitellogenin. Aquat. Toxicol. 2004;67:167-179.

48. Dussault EB, Balakrishnan VK, Sverko E, Solomon KR, Sibley PK. Toxicity of human pharmaceuticals and personal care products to benthic invertebrates. Environ. Toxicol. Chem. 2008;27 425-432.

49. Capdevielle M, Egmond RV, Whelan M, et al. Consideration of exposure and species sensitivity of triclosan in the freshwater environment. Integr. Environ. Assess. Manag. 2008;4:15-23. 
50. Ricart M, Guasch H, Alberch M, et al. Triclosan persistence through wastewater treatment plants and its potential toxic effects on river biofilms. Aquat. Toxicol. 2010;100:346-353.

51. Oliveira R, Domingues I, Grisolia CK, Soares A. Effects of triclosan on zebrafish early-life stages and adults. Environ. Sci. Pollut. Res. 2009;16:679-688.

52. Nassef M, Matsumoto S, Seki M, et al. Pharmaceuticals and ersonal care products toxicity to Japanese medaka fish (Oryzias latipes). J. Fac. Agric. Kyushu U. 2009;54:407-411.

53. Norris DO, Carr JA. Endocrine disruption: biological basis for health effects in wildlife and humans. Oxford; Oxford University Press: 2005.

54. Fort DJ, Rogers RL, Gorsuch JW, Navarro LT, Peter R, Plautz JR. Triclosan and anuran metamorphosis: no effect on tyroid-mediated metamorphosis in Xenopus laevis. Toxicol. Sci. 2010;113:392-400.

55. Fort DJ, Mathis MB, Hanson W, et al. Triclosan and thyroid-mediated metamorphosis in anurans: differentiating growth effects from thyroid-driven metamorphosis in Xenopus laevis. Toxicol. Sci. 2011;121:292-302.

56. Jacobs MN, Nolan GT, Hood SR. Lignans, bacteriocides and organochlorine compounds activate the human pregnane $\mathrm{X}$ receptor (PXR). Toxicol. Appl. Pharmacol. 2005;209:123-133.

57. Matsumura N, Ishibashi $\mathrm{H}$, Hirano $\mathrm{M}$, et al. Effects of nonylphenol and triclosan on production of plasma vitellogenin and testosterone in male South African clawed frogs (Xenopus laevis). Biol. Pharm. Bull. 2005;28:1748-1751.

58. Zorrilla LM, Gibson EK, Jeffay SC, et al. The effects of triclosan on puberty and thyroid Hormones in male wistar rats. Toxicol. Sci. 2009;107:56-64.

59. Kumar V, Chakraborty A, Kural MR, Roy P. Alteration of testicular steroidogenesis and histopathology of reproductive system in male rats treated with triclosan. Reprod. Toxicol. 2009;27:177-185.

60. Jones RD, Jampani HB, Newman JL, Lee AS. Triclosan: a review of effectiveness and safety in health care settings. Am. J. Infect. Control. 2000;28:184-196.

61. McMurry LM., Oethinger M, Levy SB. Triclosan targets lipid synthesis. Nature 1998;394:531-532.

62. Russell $\mathrm{AD}$. Biocide use and antibiotic resistance: the relevance of laboratory findings to clinical and environmental situations. Lancet. Infect. Dis. 2003;3:794-803.

63. Levy SB. Antibacterial household products: cause for concern. Emerg. Infect. Dis. 2001;7:512-515.

64. Bedoux G, Roig B, Thomas O, Dupont V, Le Bot B. Occurrence and toxicity of antimicrobial triclosan and by-products in the environment. Environ. Sci. Pollut. Res. 2012;19:1044-1065.

65. Reiss R, Mackay N, Habig C, Griffin J. An ecological risk assessment for triclosan in lotic systems following discharge from wastewater treatment plants in the United States. Environ. Toxicol. Chem. 2002;21:2483-2492.

66. Cha J, Cupples AM. Detection of the antimicrobials triclocarban and triclosan in agricultural soils following land application of municipal biosolids. Water Res. 2009;43:2522-2530.

67. Lozano N, Rice CP, Ramirez M, Torrents A. Fate of triclosan in agricultural soils after biosolid applications. Chemosphere 2010;78:760-766.
68. NICNAS T. Priority existing chemical assessment report no. 30. National Industrial Chemicals Notification and Assessment Scheme, Department of Health and Ageing, Australian Government, Sydney, Australia; 2009.

69. Kim JW, Ishibashi H, Hirano M, et al. Contamination of pharmaceutical and personal care products in sewage treatment plants and surface waters in South Korea and their removal during activated sludge treatment. J. Environ. Chem. 2010;20:127-135.

70. Behera SK, Kim HW, Oh JE, Park HS. Occurrence and removal of antibiotics, hormones and several other pharmaceuticals in wastewater treatment plants of the largest industrial city of Korea. Sci. Total Environ. 2011;409:4351-4360.

71. McAvoy DC, Schatowitz B, Jacob M, Hauk A, Eckhoff WS Measurement of triclosan in wastewater treatment systems. Environ. Toxicol. Chem. 2002;21:1323-1329.

72. Chalew TEA, Halden RU. Environmental exposure of aquatic and terrestrial biota to triclosan and triclocarban. J. Am. Water Res. Assoc. 2009;45:4-13.

73. Kim SD, Cho J, Kim IS, Vanderford BJ, Snyder SA. Occurrence and removal of pharmaceuticals and endocrine disruptors in South Korean surface, drinking, and waste waters. Water Res. 2007;41:1013-1021.

74. Ryu J, Yoon Y, Oh J. Occurrence of endocrine disrupting compounds and pharmaceuticals in 11 WWTPs in Seoul, Korea. KSCE J. Civil Eng. 2011;15:57-64.

75. Yoon Y, Ryu J, Oh J, Choi BG, Snyder SA. Occurrence of endocrine disrupting compounds, pharmaceuticals, and personal care products in the Han River (Seoul, South Korea). Sci. Total Environ. 2010;408:636-643.

76. Aguera A, Fernandez-Alba AR, Piedra L, Mezcua M, Gomez MJ. Evaluation of triclosan and biphenylol in marine sediments and urban wastewaters by pressurized liquid extraction and solid phase extraction followed by gas chromatography mass spectrometry and liquid chromatography mass spectrometry Anal. Chim. Acta 2003;480:193-205.

77. Miller TR, Heidler J, Chillrud SN, et al. Fate of triclosan and evidence for reductive dechlorination of triclocarban in estuarine sediments. Environ. Sci. Technol. 2008;42:4570-4576.

78. Lapworth DJ, Baran N, Stuart ME, Ward RS. Emerging organic contaminants in groundwater: a review of sources, fate and occurrence. Environ. Pollut. 2012;163:287-303.

79. Morales S, Canosa P, Rodriguez I, Rubi E, Cela R. Microwave assisted extraction followed by gas chromatography with tandem mass spectrometry for the determination of triclosan and two related chlorophenols in sludge and sediments. $J$. Chromatogr. A 2005;1082:128-135.

80. Ying GG, Kookana RS. Triclosan in wastewaters and biosolids from Australian wastewater treatment plants. Environ. Int. 2007;33:199-205.

81. Lee HB, Peart TE. Organic contaminants in Canadian municipal sewage sludge. Part I. Toxic or endocrine-disrupting phenolic compounds. Water Qual. Res. J. Canada 2002;37:681-696.

82. Chu SG, Metcalfe CD. Simultaneous determination of triclocarban and triclosan in municipal biosolids by liquid chromatography tandem mass spectrometry. J. Chromatogr. A 2007;1164:212-218.

83. Wu C, Spongberg AL, Witter JD, Fang M, Czajkowski KP. Uptake 
of pharmaceutical and personal care products by soybean plants from soils applied with biosolids and irrigated with contaminated water. Environ. Sci. Technol. 2010;44:6157-6161.

84. Calafat AM, Ye X, Wong LY, Reidy JA, Needham LL. Urinary concentrations of triclosan in the US population: 2003-2004. Environ. Health Perspect. 2008;116:303-307.

85. Wolff MS, Teitelbaum SL, Windham G, et al. Pilot study of urinary biomarkers of phytoestrogens, phthalates, and phenols in girls. Environ. Health Perspect. 2007;115:116-121.

86. Dirtu AC, Roosens L, Geens T, Gheorghe A, Neels H, Covaci A. Simultaneous determination of bisphenol A, triclosan, and tetrabromobisphenol A in human serum using solid-phase extraction and gas chromatography-electron capture negativeionization mass spectrometry. Anal. Bioanal. Chem. 2008;391: 1175-1181.

87. Canosa P, Rodriguez I, Rubi E, Cela R. Determination of parabens and triclosan in indoor dust using matrix solid-phase dispersion and gas chromatography with tandem mass spectrometry. Anal. Chem. 2007;79:1675-1681.

88. Adolfsson-Erici M, Allmyr M. Consumer products containing antibacterial substances - a source of human and environmental exposure? In: Stockolms Stad Report. Stockolms Stad Stockolm, Sweden; 2007.

89. Lindström A, Buerge IJ, Poiger T, Bergqvist PA, Müller MD, Buser HR. Occurrence and environmental behavior of the bactericide triclosan and its methyl derivative in surface waters and in wastewater. Environ. Sci. Technol. 2002;36:2322-2329.

90. Balmer ME, Poiger T, Droz C, et al. Occurrence of methyl triclosan, a transformation product of the bactericide triclosan, in fish from various lakes in Switzerland. Environ. Sci. Technol. 2004;38:390-395.

91. Farre M, Asperger D, Kantiani L, Gonzalez S, Petrovic M, Barcelo D. Assessment of the acute toxicity of triclosan and methyl triclosan in wastewater based on the bioluminescence inhibition of Vibrio fischeri. Anal. Bioanal. Chem. 2008;390:1999-2007.

92. Latch DE, Packer JL, Stender BL, VanOverbeke J, Arnold WA, McNeill K. Aqueous photochemistry of triclosan: formation of 2,4-dichlorophenol, 2,8-dichlorodibenzo-p-dioxin, and oligomerization products. Environ. Toxicol. Pharmacol. 2005;24: 517-525.

93. Mezcua M, Gomez MJ, Ferrer I, Aguera A, Hernando MD, Fernandez-Alba AR. Evidence of 2,7/2,8-dibenzodichloro-pdioxin as a photodegradation product of triclosan in water and wastewater samples. Anal. Chim. Acta 2004;524:241-247.

94. Lores M, Llompart M, Sanchez-Prado L, Garcia-Jares C, Cela R. Confirmation of the formation of dichlorodibenzo-p-dioxin in the photodegradation of triclosan by photo-SPME. Anal. Bioanal. Chem. 2005;381:1294-1298.

95. Buth JM, Grandbois M, Vikesland PJ, McNeill K, Arnold WA. Aquatic photochemstry of chlorinated triclosan derivatives: potential source of polychlodibenzo-p-dioxins. Environ. Toxicol. Chem. 2009;28:2555-2563.

96. Sanchez-Prado L, Llompart M, Lores M, Fernandez-Alvarez M, Garcia-Jares C, Cela R. Further research on the photo-SPME of triclosan. Anal. Bioanal. Chem. 2006;384:1548-1557.

97. Mason G, Farrell K, B Keys, Piskorska-Pliszczynska J, Safe $\mathrm{L}$, Safe S. Polychlorinated dibenzo-p-dioxins: quantitative in vitro and in vivo structure-activity relationships. Toxicol. 1986;41:21-31.

98. Canosa P, Morales S, Rodriguez I, Rubi E, Cela R, Gomez M. Aquatic degradation of triclosan and formation of toxic chlorophenols in presence of low concentrations of free chlorine. Anal. Bioanal. Chem. 2005;383:1119-1126.

99. Fiss EM, Rule KL, Vikesland PJ. Formation of chloroform and other chlorinated byproducts by chlorination of triclosan-containing antibacterial products. Environ. Sci. Technol. 2007;41: 2387-2394.

100. Rule KL, Ebbett VR, Vikesland PJ. Formation of chloroform and chlorinated organics by free-chlorine-mediated oxidation of triclosan. Environ. Sci. Technol. 2005;39:3176-3185.

101. Greyshock AE, Vikesland PJ. Triclosan reactivity chloraminated waters. Environ. Sci. Technol. 2006;40:2615-2622.

102. Hernandez-Leal L, Temmink H, Zeeman G, Buisman CJN. Removal of micropollutants from aerobically treated grey water via ozone and activated carbon. Water Res. 2011;45:2887-2896.

103. Westerhoff P, Yoon Y, Snyder S, Wert E. Fate of endocrine-disruptor, pharmaceutical, and personal care product chemicals during simulated drinking water treatment processes. Environ. Sci. Technol. 2005;39:6649-6663.

104. Nghiem LD, Coleman PJ. NF/RO filtration of the hydrophobic ionogenic compound triclosan: transport mechanisms and the influence of membrane fouling. Sep. Purif. Technol. 2008;62:709-716.

105. Sanchez-Prado L, Barro R, Garcia-Jares C, et al. Sonochemical degradation of triclosan in water and wastewater. Ultrason. Sonochem. 2008;15:689-694.

106. Lundstrom E, Adolfsson-Erici $M$, Alsberg $\mathrm{T}$, et al. Characterization of additional sewage treatment technologies: ecotoxicological effects and levels of selected pharmaceuticals, hormones and endocrine disruptors. Ecotoxicol. Environ. Saf. 2010;73:1612-1619.

107. Yu JC, Kwong TY, Luo Q, Cai ZW. Photocatalytic oxidation of triclosan. Chemosphere 2006;65:390-399.

108. Son HS, Zoh KD, Ko G. Kinetics and mechanism of photolysis and $\mathrm{TiO} 2$ photocatalysis of triclosan. J. Hazard Mater. 2009;166:954-960.

109. Son HS, Khim J, Zoh KD. Degradation of triclosan in the combined reaction of $\mathrm{Fe}^{2+}$ and UV-C: comparison with the fenton and photolytic reactions. Environ. Prog. Sustain. 2010;29:415-420.

110. Maharana D, Niu J, Rao NN, Xu Z, Shi J. Electrochemical degradation of triclosan at a $\mathrm{Ti} / \mathrm{SnO}_{2}-\mathrm{Sb} / \mathrm{Ce}-\mathrm{PbO}_{2}$ anode. CLEAN-Soil, Air, Water 2014.

111. Thompson A, Griffin P, Stuetz R, Cartmell E. The fate and removal of triclosan during wastewater treatment. Water Environ. Res. 2005;77:63-67.

112. Yu CP, Chu KH. Occurrence of pharmaceuticals and personal care products along the West Prong Little Pigeon River in east Tennessee, USA. Chemosphere 2009;75:1281-1286.

113. Taştan BE, Dönmez G. Biodegradation of pesticide triclosan by $A$. versicolor in simulated wastewater and semi-synthetic media. Pestic. Biochem. Physiol. 2015;118:33-37.

114. Lee DG, Cho KC, Chu KH. Identification of triclosan-degrading bacteria in a triclosan enrichment culture using stable isotope 
probing. Biodegradation 2014;25:55-65.

115. Ying GG, Yu XY, Kookana RS. Biological degradation of triclocarban and triclosan in a soil under aerobic and anaerobic conditions and comparison with environmental fate modelling. Environ. Pollut. 2007;150:300-305.
116. Chen X, Nielsen JL, Furgal K, Liu Y, Lolas IB, Bester K. Biodegradation of triclosan and formation of methyl-triclosan in activated sludge under aerobic conditions. Chemosphere 2011;84:452-456. 